\title{
Protonated chiral prolinamide catalyzed enantioselective direct aldol reaction in water
}

\author{
Swapandeep Singh Chimni, ${ }^{\mathrm{a}, *}$ Dinesh Mahajan ${ }^{\mathrm{a}}$ and V. V. Suresh Babu ${ }^{\mathrm{b}}$ \\ ${ }^{a}$ Department of Chemistry, Guru Nanak Dev University, Amritsar 143005, India \\ ${ }^{\mathrm{b}}$ Department of Studies in Chemistry, Central College Campus, Bangalore University, Bangalore 560 001, India
}

Received 28 April 2005; revised 15 June 2005; accepted 21 June 2005

Available online 7 July 2005

\begin{abstract}
Protonated chiral prolinamide organocatalysts have been shown to catalyze an enantioselective direct aldol process in water to provide the aldol product in high yield and good enantioselectivity. The two diastereomeric catalysts $(S, R)-\mathbf{4 b}$ and $(S, S)$-4c show different reactivity.

(C) 2005 Elsevier Ltd. All rights reserved.
\end{abstract}

Organocatalysis is the acceleration of chemical reactions with a substoichiometric amount of an organic compound, which does not contain a metal atom. ${ }^{1}$ There are very few reports of organocatalyzed synthesis in aqueous media. ${ }^{2}$ Aqueous media predominate in biological systems and it must have been the solvent used by 'Nature' in prebiotic formation of simple to complex molecules. ${ }^{3}$ A fundamental and interesting area of research is how homochirality originated in biomolecules in water during molecular evolution. ${ }^{4}$ So in order to develop enzyme mimics ${ }^{5}$ and in an attempt to understand the mechanism of the chemistry of life, catalysts having catalytic properties in water need to be developed.

We have been interested in developing an organocatalyzed enantioselective aldol reaction in water ${ }^{6}$ involving pyrrolidine-based chiral molecules. In order to achieve this objective, it is important to minimize the involvement of general base catalysis by the pyrrolidine and to enhance nucleophilic catalysis through the formation of an iminium ion. Spencer and co-workers have observed that iminium ion catalysis becomes more effective as the base strength of the amine catalysts is decreased. ${ }^{7}$ Also, it has been reported that Brönsted acids enhance the catalytic ability of pyrrolidine-based organocatalysts. ${ }^{8}$ We envisaged that such a chiral catalyst, when protonated and dissolved in water, would

\footnotetext{
Keywords: Organocatalyst; Aldol; Enamine; Water; Prolinamide.

* Corresponding author. Tel.: +91 183225 8802x3204; fax: +91 183

225 8820; e-mail: sschimni@yahoo.com
}

exist in equilibrium with the free chiral amine (Eq. 1). This would lower the effective base strength of the catalyst thus favouring iminium ion catalysis, as observed by Spencer.

So we prepared protonated chiral prolinamides to check our hypothesis. To our surprise, we found these molecules act as effective organocatalysts for direct cross aldol reaction of acetone with $p$-nitrobenzaldehyde in water. In this communication, we illustrate this concept through enantioselective catalysis using phenethylamine prolinamide hydrobromide salt.

$$
\stackrel{+}{\mathrm{RNH}_{3}} \mathbf{X}^{-} \stackrel{\mathrm{H}_{2} \mathrm{O}}{=} \mathrm{RNH}_{2}+\mathrm{H}^{+}+\mathbf{X}^{-}
$$

Initial investigations on the aldol reaction of acetone $\mathbf{1}$ and $p$-nitrobenzaldehyde $\mathbf{2}$ in water using catalyst $\mathbf{4 a}$ ( $20 \mathrm{~mol} \%$ ) provided aldol adduct 3 in $92 \%$ yield and $33 \%$ ee (Table 1 , entry 1 ). ${ }^{9}$ Using proline as the catalyst, under similar conditions gave racemic 3 in $78 \%$ yield. ${ }^{10}$ Encouraged by this result, we prepared enantiomerically pure $(S, R)-\mathbf{4 b}$ and $(S, S)-\mathbf{4 c}$ and performed the aldol reaction using them as catalysts in water and obtained 3 in $45 \%$ and $39 \%$ ee, respectively (Table 1 , entries 2 and 9). The variations in the amount of water suggest that a lower concentration of water slightly improves the enantioselectivity (entries 2, 3 and 4). Lower catalyst loading does not have any effect on the enantioselectivity but it results in a longer reaction time. Performing the reaction at a lower temperature resulted in an increase in the enantioselectivity to $56 \%$ (entry 6 ). In the absence of water, the reaction did not occur. The same 
Table 1. Phenethylamine prolinamide HBr 4-catalyzed asymmetric aldol reaction

\begin{tabular}{|c|c|c|c|c|c|c|c|}
\hline Entry & Catalyst (mol \%) & Acetone $(\mathrm{mL})$ & Water $(\mathrm{mL})$ & Solvent, acetone:water & Time & $\begin{array}{l}\text { Yield (\%) } \\
\mathbf{3}\end{array}$ & $\%$ ee \\
\hline 1 & 4a $(20)$ & 3 & 3 & $1: 1$ & $8 \mathrm{~h}$ & 92 & $33(R)$ \\
\hline 2 & $4 \mathbf{b}(20)$ & 3 & 3 & $1: 1$ & $40 \mathrm{~h}$ & 89 & $45(R)$ \\
\hline 3 & $4 b(20)$ & 3 & 1.5 & $2: 1$ & $40 \mathrm{~h}$ & 89 & $48(R)$ \\
\hline 4 & $4 \mathbf{b}(20)$ & 3 & 0.735 & $4: 1$ & $40 \mathrm{~h}$ & 86 & $50(R)$ \\
\hline 5 & $\mathbf{4 b}(5)$ & 3 & 0.735 & $4: 1$ & $72 \mathrm{~h}$ & 88 & $49(R)$ \\
\hline 6 & $4 \mathbf{b}(20)^{\mathrm{a}}$ & 3 & 0.735 & $4: 1$ & $60 \mathrm{~h}$ & 60 & $56(R)$ \\
\hline 7 & $\mathbf{4 b}(20)$ & 1.5 & 1.5 & $1: 1$ & $40 \mathrm{~h}$ & 69 & $39(R)$ \\
\hline 8 & $4 \mathbf{b}(20)$ & 3 & - & - & $5 \mathrm{~d}$ & Traces & nd \\
\hline 9 & $4 c(20)$ & 3 & 3 & $1: 1$ & $6 \mathrm{~h}$ & 87 & $39(R)$ \\
\hline 10 & $4 c(20)$ & 3 & 0.735 & $4: 1$ & $24 \mathrm{~h}$ & 78 & $38(R)$ \\
\hline 11 & $4 c(20)$ & 3 & - & - & $5 \mathrm{~d}$ & Traces & nd \\
\hline 12 & $5(20)$ & 3 & 3 & $1: 1$ & $3 \mathrm{~h}$ & 87 & $16(R)$ \\
\hline 13 & Proline (20) & 3 & 3 & $1: 1$ & $3 \mathrm{~h}$ & 78 & - \\
\hline
\end{tabular}

${ }^{\text {a }}$ Reaction performed at $0-4{ }^{\circ} \mathrm{C}$.

reaction when catalyzed with phenethylamine prolinamide 5 in water afforded 3 in 16\% ee (entry 12) highlighting the importance of protonation of the catalyst in achieving higher enantioselectivity. This study also highlights the difference in the reactivity and enantioselectivity of the two diastereomeric catalysts $(\mathbf{4 b}$ and $\mathbf{4 c})$ in water where $\mathbf{4 b}$ provided higher enantioselectivity but showed lower reactivity, on the other hand $\mathbf{4 c}$ provided lower enantioselectivity but higher reactivity. Thus, protonated phenethylamine prolinamide $\mathbf{4 b}$ catalyzes the direct cross aldol reaction of $\mathbf{1}$ and $\mathbf{2}$ in water with $56 \%$ enantioselectivity at $0-4{ }^{\circ} \mathrm{C}$. To the best of our knowledge this constitutes the first report on the use of a protonated chiral amine as an enantioselective catalyst in water (Scheme 1).
Further, it was decided to study the effect of solvents on the course of the reaction. The results are given in Table 2. Solvents such as DMSO, DMF and THF slowed the reaction rate. In the case of catalyst $4 \mathbf{b}$ the various solvents were found to have no detrimental effect on the enantioselectivity of the reaction but in the case of catalyst $\mathbf{4 c}$ lower enantioselectivity was observed.

In all the studied cases, the aldol adduct 3 was found to possess the same $(R)$-absolute configuration as obtained in the aldol reactions catalyzed by L-proline in nonaqueous medium. ${ }^{11}$ The stereochemistry of the process can be rationalized by invoking the transition state represented in Figure 1, involving a proton-mediated six-membered cyclic transition state with additional

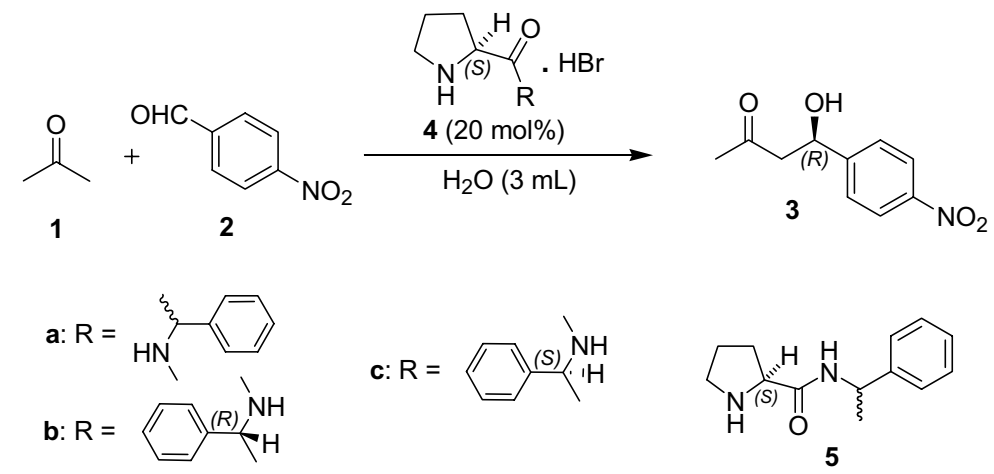

Scheme 1.

Table 2. Effect of solvent on the aldol reaction between acetone and $p$-nitrobenzaldehyde catalyzed by $\mathbf{4 b} / \mathbf{4 c}$

\begin{tabular}{|c|c|c|c|c|c|c|c|}
\hline Entry & Catalyst 4 & Acetone (mL) & Water $(\mathrm{mL})$ & Solvent (mL) & Time & $\begin{array}{l}\text { Yield }(\%) \\
\mathbf{3}\end{array}$ & $\%$ ee \\
\hline 1 & $\mathbf{b}$ & 1.5 & 1.5 & DMSO (1.5) & $24 \mathrm{~h}$ & 80 & 40 \\
\hline 2 & $\mathbf{b}$ & 1.5 & 1.5 & THF (1.5) & $48 \mathrm{~h}$ & 78 & 48 \\
\hline 3 & $\mathbf{b}$ & 1.5 & 1.5 & DMF (1.5) & $24 \mathrm{~h}$ & 69 & 39 \\
\hline 4 & c & 1.5 & 1.5 & DMF (1.5) & $7 \mathrm{~h}$ & 71 & 40 \\
\hline 5 & c & 1.5 & 1.5 & DMSO (1.5) & $20 \mathrm{~h}$ & 85 & 26 \\
\hline 6 & c & 1.5 & 1.5 & THF (1.5) & $16 \mathrm{~h}$ & 85 & 27 \\
\hline 7 & $\mathbf{a}$ & 1.5 & 1.5 & PEG (1.5) & $10 \mathrm{~d}$ & 60 & 32 \\
\hline
\end{tabular}




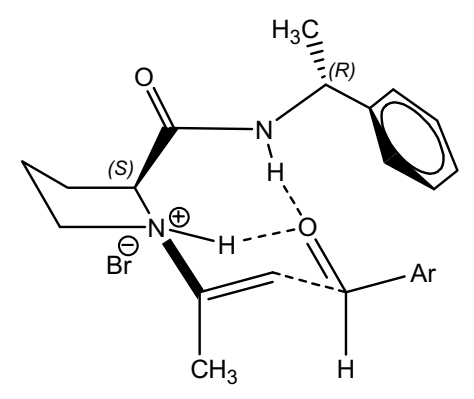

Figure 1.

activation and orientation of the aldehyde by the amide proton. The favourable hydrophobic interaction of the aromatic groups of the catalyst and the aldehyde enforces the asymmetric environment.

Small peptides have proven to be promising organic catalysts for a number of important transformations. ${ }^{12}$ We evaluated the catalytic ability of two dipeptide salts, Pro-Phe-TFA and Pro-Ala-TFA, in water for the enantioselective aldol reaction. The catalyst Pro-Phe-TFA gave 3 in $38 \%$ yield and $40 \%$ ee in 10 days while Pro-Ala-TFA gave no reaction in the same time. The inactivity of the latter dipeptide as compared to the former may be because of the absence of the hydrophobic interactions between catalyst and the aldehyde, which constitute an integral part of the orientation and activation process.

In summary, we have shown that chiral protonated prolinamide derivatives are useful asymmetric catalysts in water for aldol processes. This methodology addresses environmental concerns and encompasses the principles of Green chemistry. Further refinement of the catalytic structure and extension of the utility of the new methodology to synthetically relevant organic processes are under active investigation.

\section{Acknowledgements}

S.S.C. thanks CSIR, India, for financial support (Research grant No. 01/1878/03/EMR-II). DM thanks UGC, India, for a junior research fellowship. The support of Dr. S. C. Taneja and Dr. K. N. Singh is gratefully acknowledged.

\section{References and notes}

1. (a) Dalko, P. I.; Moissan, L. Angew. Chem., Int. Ed. 2001, 40, 3726-3748; (b) List, B. Tetrahedron 2002, 58, 55735590; (c) Jarvo, E. R.; Miller, S. J. Tetrahedron 2002, 58, 2481-2495; (d) Schreiner, P. R. Chem. Soc. Rev. 2003, 32, 289-296; (e) Franc, S.; Guerin, D. J.; Millar, S. J.; Leckta, T. Chem. Rev. 2003, 103, 2985-3012; (f) Dalko, P. I.; Moissan, L. Angew. Chem., Int. Ed. 2004, 43, 5123-5175; (g) Seayad, J.; List, B. Org. Biomol. Chem. 2005, 3, 719724; For an issue dedicated to organocatalysis, see: $A d v$. Synth. Catal. 2004, 346(9-10); Acc. Chem. Res. 2004, $37(8)$.

2. (a) Dickerson, T. J.; Janda, K. D. J. Am. Chem. Soc. 2002, 124, 3220-3221; (b) Cordova, A.; Notz, W.; Barbas, C. F., III. Chem. Commun. 2002, 3024-3025; (c) Reymond, J.-L.; Chen, Y. J. Org. Chem. 1995, 60, 6970-6979; (d) Dickerson, T. J.; Lovell, T.; Meijler, M. M.; Noodleman, L.; Janda, K. D. J. Org. Chem. 2004, 69, 6603-6609; For peptide-catalyzed enantioselective aldol reaction in water using hydroxy acetone as donor, see: Tang, Z.; Yang, Z. H.; Cun, L.-F.; Gong, L.-Z.; Mi, A.-Q.; Jiang, Y.-Z. Org. Lett. 2004, 6, 2285-2287.

3. (a) Weber, A. L. Origin Life 2001, 31, 71; (b) Krishnamurthy, R.; Pitsch, S.; Arrhenius, G. Origin Life Evol. Biosphere 1998, 29, 139; (c) Graaf, R. M. D.; Visscher, J.; Schwartz, A. W. Orig. Life Evol. Biosphere 1998, 28, 271282; (d) Graaf, R. M. D.; Visscher, J.; Xu, Y.; Arrhenius, G.; Schwartz, A. W. J. Mol. Evol. 1998, 47, 501-507; (e) Sutherland, J. D.; Whitfield, J. N. Tetrahedron 1997, 53, 11493-11527.

4. (a) Pizzarello, S.; Weber, A. L. Science 2004, 303, 1151; (b) Siegel, J. S. Chirality 1998, 10, 24-27, and references cited therein.

5. Breslow, R. Chem. Biol. 1998, 5, R27-R28.

6. Chimni, S. S.; Mahajan, D. Tetrahedron 2005, 61, 50195025.

7. Roberts, R. D.; Ferran, H. E.; Gula, J. M.; Spencer, T. A. J. Am. Chem. Soc. 1980, 102, 7054-7058.

8. (a) Mase, N.; Tanaka, F.; Barbas, C. F., III. Org. Lett. 2003, 5, 4369-4372; (b) Ji, C.; Peng, Y.; Huang, C.; Wang, N.; Jiang, Y. Synlett 2005, 6, 986-990; For protonated chiral diamines, see: (c) Nakadai, M.; Saito, S.; Yamamoto, H. Tetrahedron 2002, 58, 8167-8177; (d) Nakadai, M.; Saito, S.; Yamamoto, H. Synlett 2001, 1245-1248; (e) Saito, S.; Yamamoto, H. Acc. Chem. Res. 2004, 37, 570; , For an excellent review on protonated chiral catalysts, see: Bolm, C.; Rantanen, T.; Schiffers, I.; Zani, L. Angew. Chem., Int. Ed. 2005, 44, 1758-1763.

9. Representative experimental procedure for the aldol reaction: To a stirred mixture of $\mathbf{2}(302 \mathrm{mg}, 2 \mathrm{mmol}), \mathbf{1}$ $(20 \mathrm{mmol})$ and water $(3 \mathrm{~mL})$, prolinamide $\mathrm{HBr}$ (4) $(20 \mathrm{~mol} \%)$ was added. The reaction was monitored by TLC. The reaction was quenched with saturated ammonium chloride solution and extracted with $\mathrm{CH}_{2} \mathrm{Cl}_{2}$. The organic layer was dried over anhydrous $\mathrm{Na}_{2} \mathrm{SO}_{4}$ and distilled to obtain the crude product. Column chromatography of the crude on silica gel (60-120 mesh) using a mixture of ethyl acetate and hexane in varying proportions as eluent, gave pure product $3{ }^{6}$ The enantiomeric excess of 3 was determined on HPLC using a Chiralpak AS-H column (IPA/hexane; 3:7).

10. On the referee's suggestion, the reaction of $\mathbf{1}$ and $\mathbf{2}$ was performed in the presence of proline and $\mathrm{HBr}$. Running the reaction for $24 \mathrm{~h}$ did not yield any product.

11. (a) List, B.; Lerner, R. A.; Barbas, C. F., III. J. Am. Chem. Soc. 2000, 122, 2395-2396; (b) List, B.; Notz, W. J. Am. Chem. Soc. 2000, 122, 7386-7387; (c) Northrup, A. B.; MacMillan, D. W. C. J. Am. Chem. Soc. 2002, 124, 67986799; (d) Sakthivel, K.; Notz, W.; Bui, T.; Zhong, G.; Barbas, C. F., III J. Am. Chem. Soc. 2001, 123, 5260-5267.

12. Miller, S. J. Acc. Chem. Res. 2004, 8, 601. 